\title{
Levosimendan and mortality after coronary revascularisation: a meta-analysis of randomised controlled trials
}

\author{
Ritesh Maharaj and Victoria Metaxa
}

\begin{abstract}
Introduction: Patients undergoing coronary revascularization often require inotropic support that has been associated with an increased risk for death and morbidity. The purpose of this study was to evaluate the effect of levosimendan versus control on survival after coronary revascularization.

Methods: A systemic review and meta-analysis of the literature was carried out on published randomized controlled clinical trials that investigated the efficacy of levosimendan compared to other therapy in patients having coronary revascularisaion. The databases searched were Pubmed, EMBASE, the Cochrane Registry of Clinical Trials and the metaRegister of Controlled Trials. Studies that compared levosimendan to any other therapy for coronary revascularisation in adult humans and reported at least one outcome of interest were considered for inclusion. Both percutaneous coronary intervention and cardiac surgery were included. Data extraction was performed independently by two reviewers using predefined criteria. Relevant outcomes included mortality, cardiac index, cardiac enzymes, length of stay and post-procedural atrial fibrillation.

Results: The meta-analysis included 729 patients from 17 studies. Levosimendan was associated with a mortality reduction after coronary revascularization, (19/386 in the levosimendan group vs 39/343 in the control arm) odds ratio (OR) 0.40 ( $95 \%$ confidence interval $(C l) 0.21$ to 0.76 , $P$ for overall effect $0.005, P$ for heterogeneity $=0.33, I^{2}=$ $12 \%$ with a total of 729 patients. Levosimendan also had a favourable effect on cardiac index (standardised mean difference $1.63,95 \% \mathrm{Cl} 1.43$ to $1.83, \mathrm{P}$ for overall effect $<0.00001$ ), length of intensive care stay (random effects model, mean difference -26.18 hours $95 \% \mathrm{Cl} 46.20$ to $6.16, P$ for heterogeneity $<0.00001, I^{2}=95 \%$, $P$ for overall effect $P=0.01$ ), reductions in the rate of atrial fibrillation (OR $0.54,95 \% \mathrm{Cl} 0.36$ to 0.82 , $P$ for effect $=0.004, P$ for heterogeneity $0.84, I^{2}=0 \%$ for 465 patients) and troponin I levels group (mean difference $-1.59,95 \% \mathrm{Cl} 1.78$ to 1.40 , $P$ for overall effect $<0.00001, P$ for heterogeneity $<0.00001, I^{2}=95 \%$ ). Limitations of this analysis are discussed.

Conclusions: Levosimendan is associated with a significant improvement in mortality after coronary revascularization. There are also improvements in several secondary endpoints. A suitably powered randomised controlled trial is required to confirm these findings and to address the unresolved questions about the timing and dosing of levosimendan.
\end{abstract}

\section{Introduction}

Following coronary revascularisation, patients are still vulnerable to a low cardiac output state and tissue hypoperfusion. Some patients may require bridging therapy in order to realise the benefits of revascularisation. There is substantial geographic variation, but it is

\footnotetext{
* Correspondence: r1teshmah@yahoo.co.uk

Kings College Hospital, Denmark Hill, London, SE5 9RS, UK
}

estimated that between 8 and $25 \%$ of patients undergoing coronary revascularisation require inotropic support for myocardial dysfunction [1-3]. This group of patients carry a substantial burden of morbidity and mortality [4]. Pharmacologic support is commonly limited to catecholaminesand phosphodiesterase III inhibitors (PDEIs) with levosimendan gaining prominence [5]. There is a lack of suitably powered randomised control trails to guide the choice of inotrope in this group of

\section{() Biomed Central}


patients. Both catecholamines and PDEIs are associated with increased post-operative myocardial oxygen consumption and arrythmogenesis [6]. Additionally catecholamines have also been associated with impaired coronary vasodilatatory reserve [7].

Levosimendan sensitises myofilaments to calcium by binding to the calcium saturated troponin $\mathrm{C}$, increasing their load-independent contraction [8]. The pleiotropic effects of levosimendan include vasodilatation by opening ATP-sensitive potassium channels $\left(\mathrm{K}_{\mathrm{ATP}}\right)$ in vascular smooth muscle as well as in mitochondrial $\mathrm{K}_{\mathrm{ATP}}$ channels.

Early clinical trials, though underpowered, have suggested that levosimendan would be useful in the setting of post coronary revascularisation myocardial dysfunction. More recently there have been several completed clinical trials in this group of patients. The principal objective of this study was to evaluate the association between levosimendan, compared with conventional therapy on mortality, in randomised control trialsin patients having coronary revascularisation.

\section{Materials and methods}

\section{Search strategy}

The primary search for randomised clinical trials (RCTs) was conducted using Pubmed, EMBASE and the Cochrane Registry of Clinical Trials. The search term used was 'levosimendan'. The search was combined with filters to identify RCTs in the Pubmed and EMBASE database and is available as supplementary material (see Additional file 1 for details). We also searched the metaRegister of Controlled Trials using the term 'levosimendan' [9]. No language restriction was placed but the search was limited to adult human subjects. We used backward snowballing by reviewing the bibliographies of included RCTs and review articles to identify otherwise unrecognised publications. The electronic database search included publications from 1966 and was finalised on 31 August 2010. The study did not require ethical approval.

\section{Study selection}

The authors reviewed all abstracts to identify potential RCTs in a standardised manner. The inclusion criteria were reports of RCTs that compared levosimendan to any other therapy for coronary revascularisation in adult humans and reported at least one outcome of interest. Relevant outcomes included mortality, haemodynamic parameters (for example, cardiac index), cardiac enzymes, length of stay and post-procedural atrial fibrillation. If the abstract suggested that the study could potentially meet the inclusion criteria, the full text article was then retrieved and reviewed. Disagreements between reviewers were resolved by consensus.

\section{Data abstraction and study characteristics}

All included studies were assessed for internal validity and risk of bias according to the Cochrane Collaboration methods. Each report was assessed for the adequacy of allocation concealment, blinding, performance of an intention to treat analysis and the extent of loss to follow-up.

Data included baseline patient characteristics including age and co-morbidity, baseline left ventricular ejection fraction, details of levosimendan dose and specifics of comparator therapy, type of coronary revascularisation, haemodynamic and clinical outcome data. When data was missing attempts were made to contact the authors.

\section{Data synthesis and analysis}

Agreement on inclusion of studies was assessed using the kappa statistic. Heterogeneity was measured using the Cochrane Q test and quantified with the $I^{2}$ statistic. An $I^{2}$ value of $>50 \%$ was considered at least moderate heterogeneity.

Data from individual studies were collected to allow calculation of odds ratio (OR). The primary analysis was conducted by means of the Peto fixed effects method when $\mathrm{I}^{2}<25 \%$ and with the random effects model when $\mathrm{I}^{2}>25 \%$. Weighted mean difference (WMD) and 95\% CI were calculated for continuous variables (haemodynamics and troponin I). The potential for bias was assessed by visual inspection of funnel plots. Sensitivity analyses were conducted by comparing the fixed and random effects models as well as by evaluating the risk of mortality in studies with a low risk of bias only. The analysis was performed using statistical software SPSS 16 (SPSS Chicago, IL, USA) and Revman 5.0 (available from the Cochrane Collaboration Group). The study was performed in compliance with the Preferred Reporting Items for Systematic Reviews and Meta-analysis (PRISMA) statement $[10,11]$.

\section{Results}

There were 680 reports identified by the search, 79 full text articles retrieved for in depth review. We identified 17 eligible studies involving 729 patients that were included in the final analysis. Figure 1 describes the flow and reasons for exclusion. Agreement on study inclusion was reached in 76 of the 79 cases $($ kappa $=0.92)$. The characteristics of the included studies are described in Table 1. An appraisal of study quality and risk of bias is presented in Table 2. Overall studies were of variable quality and many reports lacked relevant details to assess selection, performance or reporting bias. A risk of bias graph is included in the supplementary material (see Additional file 2 for details). 


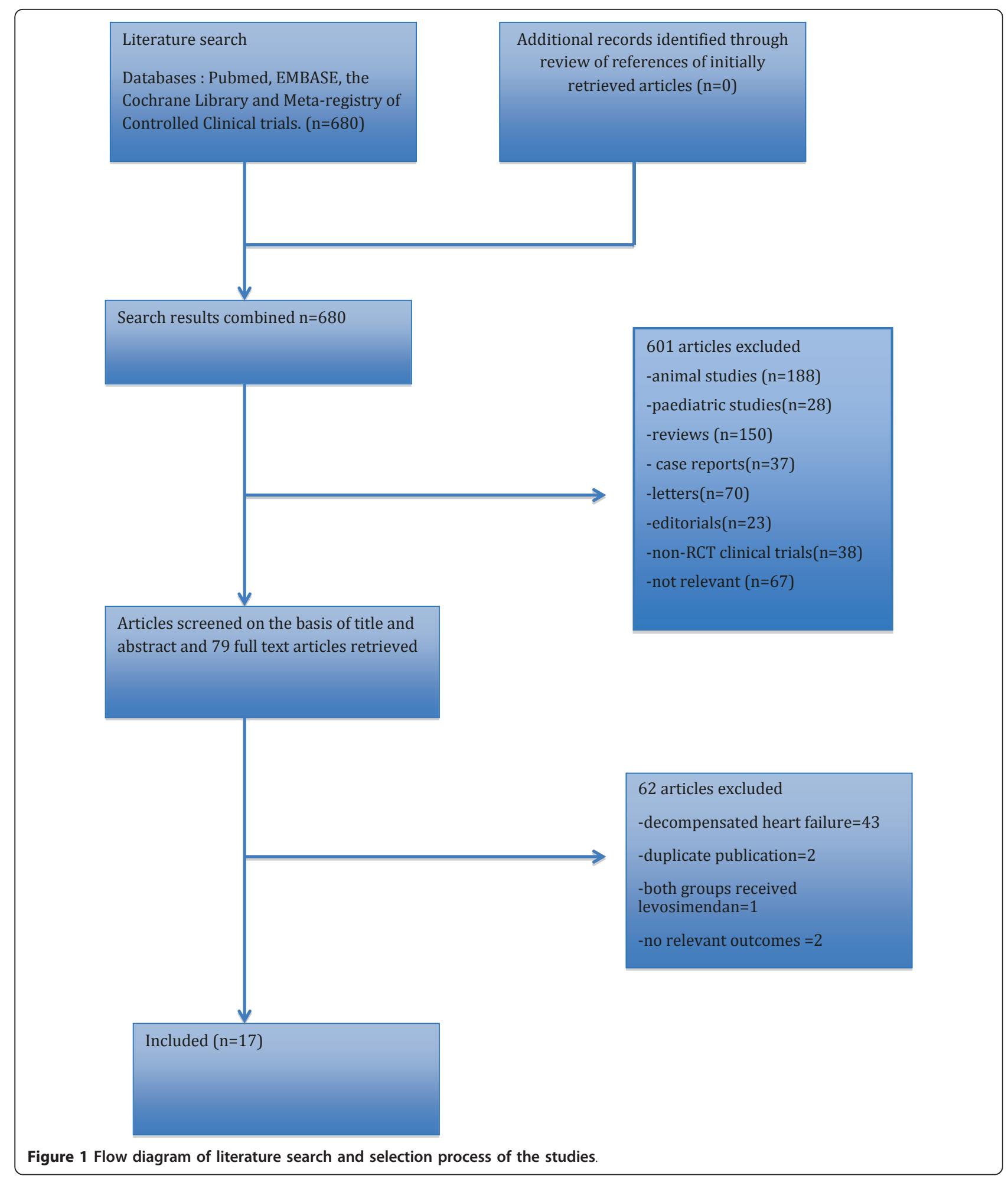

Analysis of the data showed that, compared with a control intervention, levosimendan was associated with a significant mortality reduction, (19/387 in the levosimendan group vs 39/342 in the control arm) OR 0.41
(95\% CI 0.23 to $0.74, P$ for overall effect $0.005, P$ for heterogeneity $=0.33, \mathrm{I}^{2}=12 \%$ with a total of 729 patients) (Figure 2). A subgroup analysis comparing the effect of levosimendan on mortality in elective versus 
Table 1 Description of the studies included in the meta-analysis

\begin{tabular}{|c|c|c|c|c|c|c|c|c|c|c|}
\hline \multirow[t]{2}{*}{ Source } & \multirow[t]{2}{*}{ Year } & \multirow[t]{2}{*}{ Patients } & \multicolumn{2}{|c|}{$\begin{array}{c}\text { Mean Age } \\
\text { (years } \pm \text { SD) }\end{array}$} & \multirow[t]{2}{*}{ Setting } & \multirow[t]{2}{*}{$\begin{array}{c}\text { Time of } \\
\text { administration }\end{array}$} & \multicolumn{2}{|c|}{$\begin{array}{c}\text { Mean Baseline LVEF \% } \\
\pm \text { SD }\end{array}$} & \multirow[t]{2}{*}{ Control } & \multirow[t]{2}{*}{$\begin{array}{l}\text { Follow- } \\
\text { up }\end{array}$} \\
\hline & & & Levosimendan & Control & & & Levosimendan & Control & & \\
\hline $\begin{array}{l}\text { Al-Shawaf } \\
\text { et al. [35] }\end{array}$ & 2006 & 30 & $60.5 \pm 11$ & $58 \pm 10$ & $\begin{array}{l}\text { Type } 2 \text { diabetes } \\
\text { with LCOS after } \\
\text { CABG. }\end{array}$ & $\begin{array}{c}\text { Post } \\
\text { intervention }\end{array}$ & $29 \pm 6$ & $31 \pm 6$ & Milrinone & $\begin{array}{l}\text { Hospital } \\
\text { stay }\end{array}$ \\
\hline $\begin{array}{c}\text { Alvarez et al. } \\
{[36]}\end{array}$ & 2005 & 30 & $71.5 \pm 5.2$ & $\begin{array}{c}71.9 \pm \\
5.2 \\
\end{array}$ & $\begin{array}{c}\text { Elective CABG with } \\
\text { LCOS }\end{array}$ & $\begin{array}{c}\text { Post } \\
\text { intervention }\end{array}$ & $35 \pm 5$ & $37 \pm 4$ & Dobutamine & $\begin{array}{c}\text { Hospital } \\
\text { stay }\end{array}$ \\
\hline $\begin{array}{c}\text { Alvarez et al. } \\
\text { [37] } \\
\end{array}$ & 2006 & 50 & $71.2 \pm 7.2$ & $\begin{array}{c}67.0 \pm \\
8.0\end{array}$ & $\begin{array}{c}\text { Elective CABG with } \\
\text { LCOS }\end{array}$ & $\begin{array}{c}\text { Post } \\
\text { intervention }\end{array}$ & $35 \pm 4$ & $34 \pm 5$ & Dobutamine & $\begin{array}{c}\text { Hospital } \\
\text { stay }\end{array}$ \\
\hline $\begin{array}{c}\text { Barisin et al. } \\
\text { [38] }\end{array}$ & 2004 & 33 & $62.4 \pm 7.1$ & $\begin{array}{c}57.9 \pm \\
10.4\end{array}$ & $\begin{array}{l}\text { Elective OPCAB } \\
\text { with good LV } \\
\text { function }\end{array}$ & $\begin{array}{c}\text { Pre- } \\
\text { intervention }\end{array}$ & $62 \pm 8$ & $58 \pm 10$ & Placebo & $\begin{array}{l}\text { Hospital } \\
\text { stay }\end{array}$ \\
\hline $\begin{array}{c}\text { De Hert et al. } \\
{[39]} \\
\end{array}$ & 2007 & 30 & $67 \pm 11$ & $69 \pm 10$ & Elective CABG & Intraoperatively & $24 \pm 6$ & $27 \pm 3$ & Milrinone & $\begin{array}{l}\text { Hospital } \\
\text { stay }\end{array}$ \\
\hline $\begin{array}{l}\text { De Hert et al. } \\
{[40]}\end{array}$ & 2008 & 60 & $67.5 \pm 9.5$ & $69 \pm 10$ & Elective CABG & Inraoperatively & $22 \pm 5$ & $25 \pm 3$ & Milrinone & $\begin{array}{l}\text { Hospital } \\
\text { stay }\end{array}$ \\
\hline $\begin{array}{c}\text { De Luca et al. } \\
{[41]}\end{array}$ & 2005 & 26 & $58.6 \pm 8.7$ & $\begin{array}{c}57.1 \pm \\
9.3\end{array}$ & $\begin{array}{c}\text { Acute } \mathrm{Ml} \\
\text { undergoing } \mathrm{PCl}\end{array}$ & $\begin{array}{c}\text { Post } \\
\text { intervention }\end{array}$ & $28 \pm 3$ & $30 \pm 3$ & Placebo & $\begin{array}{l}\text { Hospital } \\
\text { stay }\end{array}$ \\
\hline $\begin{array}{c}\text { Eriksson et al. } \\
\text { [42] }\end{array}$ & 2009 & 60 & $64 \pm 10$ & $64 \pm 10$ & $\begin{array}{c}\text { Elective CABG with } \\
\text { LVEF }<50 \%\end{array}$ & Intraoperatively & $36 \pm 8$ & $36 \pm 8$ & Placebo & $\begin{array}{l}\text { Hospital } \\
\text { stay }\end{array}$ \\
\hline $\begin{array}{l}\text { Fuhrmann } \\
\text { et al. [33] }\end{array}$ & 2008 & 32 & $68 \pm 74$ & $\begin{array}{c}68 \pm \\
8.1 \\
\end{array}$ & $\begin{array}{l}\text { Cardiogenic shock } \\
\text { after acute Ml }\end{array}$ & $\begin{array}{c}\text { Post } \\
\text { intervention }\end{array}$ & $22 \pm 9$ & $27 \pm 10$ & Enoximone & $\begin{array}{c}\text { Hospital } \\
\text { stay }\end{array}$ \\
\hline $\begin{array}{l}\text { Husedzinovic } \\
\text { et al. [43] }\end{array}$ & 2005 & 24 & $61 \pm 5.4$ & $\begin{array}{c}61 \pm \\
5.3 \\
\end{array}$ & $\begin{array}{c}\text { Elective OPCAB } \\
\text { with normal LVEF }\end{array}$ & $\begin{array}{c}\text { Pre- } \\
\text { intervention }\end{array}$ & $56 \pm 5$ & $59 \pm 2$ & placebo & $\begin{array}{c}\text { Hospital } \\
\text { stay }\end{array}$ \\
\hline $\begin{array}{c}\text { Jarvela et al. } \\
{[44]}\end{array}$ & 2008 & 24 & $69 \pm 11$ & $67 \pm 10$ & $\begin{array}{c}\text { Elective AVR and } \\
\text { CABG }\end{array}$ & Intraoperatively & $50 \pm 4$ & $65 \pm 5$ & Placebo & $\begin{array}{c}\text { Hospital } \\
\text { stay }\end{array}$ \\
\hline $\begin{array}{c}\text { Levin et al. } \\
{[45]}\end{array}$ & 2008 & 137 & 62.4 & 61.7 & $\begin{array}{c}\text { LCOS after elective } \\
\text { CABG }\end{array}$ & $\begin{array}{c}\text { Post } \\
\text { intervention }\end{array}$ & $37 \pm 4$ & $38 \pm 5$ & Dobutamine & $\begin{array}{c}\text { Hospital } \\
\text { stay }\end{array}$ \\
\hline $\begin{array}{l}\text { Lilleberg } \\
\text { et al. [46] }\end{array}$ & 1998 & 23 & $56.9 \pm 7.9$ & $\begin{array}{c}59 \pm \\
5.7\end{array}$ & $\begin{array}{l}\text { Elective low risk } \\
\text { CABG }\end{array}$ & $\begin{array}{c}\text { Post } \\
\text { intervention }\end{array}$ & $61 \pm 9$ & $58 \pm 9$ & Placebo & $\begin{array}{c}\text { Hospital } \\
\text { stay }\end{array}$ \\
\hline $\begin{array}{l}\text { Samimi-Fard } \\
\text { et al. [47] }\end{array}$ & 2008 & 22 & $65 \pm 12$ & $63 \pm 11$ & $\begin{array}{c}\text { Acute Ml with } \\
\text { Cardiogenic shock } \\
\text { after PCl }\end{array}$ & $\begin{array}{c}\text { Post } \\
\text { intervention }\end{array}$ & $29 \pm 2$ & $30 \pm 3$ & Dobutamine & $\begin{array}{l}\text { Two } \\
\text { years }\end{array}$ \\
\hline $\begin{array}{c}\text { Sonntag et al. } \\
{[48]}\end{array}$ & 2004 & 24 & 60 & 60 & $\mathrm{PCl}$ after acute $\mathrm{Ml}$ & $\begin{array}{c}\text { Post } \\
\text { intervention }\end{array}$ & $58 \pm 3$ & $62 \pm 4$ & Placebo & $\begin{array}{c}\text { Hospital } \\
\text { stay }\end{array}$ \\
\hline $\begin{array}{l}\text { Tritapepe } \\
\text { et al. [49] }\end{array}$ & 2006 & 24 & $66.5 \pm 5.9$ & $\begin{array}{l}69.5 \pm \\
5.6\end{array}$ & Elective CABG & $\begin{array}{c}\text { Pre- } \\
\text { intervention }\end{array}$ & $50 \pm 7$ & $52 \pm 5$ & Placebo & $\begin{array}{c}\text { Hospital } \\
\text { stay }\end{array}$ \\
\hline $\begin{array}{l}\text { Tritapepe } \\
\text { et al. [1] }\end{array}$ & 2009 & 106 & $66.5 \pm 7.8$ & 64. \pm 8 & Elective CABG & $\begin{array}{c}\text { Pre- } \\
\text { intervention }\end{array}$ & $44 \pm 10$ & $42 \pm 11$ & Placebo & $\begin{array}{c}\text { Hospital } \\
\text { stay }\end{array}$ \\
\hline
\end{tabular}

CABG, coronary artery bypass graft; LCOS, low cardiac output state; LVEF, left ventricular ejection fraction; MI, myocardial infarction; OPCAB, off pump coronary artery bypass graft; $\mathrm{PCl}$, primary coronary intervention.

emergency coronary revascularisation was performed. The elective revascularisation showed a statistically significant mortality benefit compared with the emergency revascularisation group (OR $0.36,95 \% \mathrm{CI} 0.18$ to $0.72, P$ for overall effect $=0.003, \mathrm{I}^{2}=0 \%$ compared with OR $0.61,95 \%$ CI 0.19 to $1.89, P$ for overall effect $=0.39, \mathrm{I}^{2}$ $=69 \%$ respectively). All the emergency revascularisations were PCI. The overall result was consistent when a random effects model was used (OR 0.43 (95\% CI 0.21 to 0.89)).

Levosimendan had a favourable effect on cardiac index (standardised mean difference $1.63,95 \%$ CI 1.43 to 1.83 , $P$ for overall effect $<0.00001)$ although there was significant heterogeneity $\left(P<0.000001 \mathrm{I}^{2}=95 \%\right)$. A sub-group analysis was undertaken to explore the heterogeneity. Subgroups were defined by the comparator drug, that is, the placebo, dobutamine or phosphdiesterase inhibitors. The sub-group analysis did not show any difference in treatment effect (Figure 3).

Post revascularisation, troponin I levels were significantly higher in the control group compared with the levosimendan group (mean difference -1.59, 95\% CI 1.78 to $1.40, P$ for overall effect $<0.00001, P$ for heterogeneity $<0.00001, \mathrm{I}^{2}=95 \%$ ) with 361 patients included (Figure 4).

There was a significantly lower rate of post-revascularisation new-onset atrial fibrillation in the levosimendan 
Table 2 Risk of bias assessment of included studies

\begin{tabular}{|c|c|c|c|c|c|c|c|c|}
\hline Source & $\begin{array}{l}\text { Adequate } \\
\text { sequence } \\
\text { generation }\end{array}$ & $\begin{array}{l}\text { Allocation } \\
\text { concealment }\end{array}$ & Blinding & $\begin{array}{l}\text { Incomplete } \\
\text { outcome data } \\
\text { addressed }\end{array}$ & $\begin{array}{c}\text { Free of } \\
\text { selective } \\
\text { reporting }\end{array}$ & $\begin{array}{l}\text { Free of } \\
\text { other } \\
\text { Bias }\end{array}$ & $\begin{array}{l}\text { Concurrent } \\
\text { therapies } \\
\text { similar }\end{array}$ & $\begin{array}{l}\text { Overall } \\
\text { risk of } \\
\text { bias }\end{array}$ \\
\hline $\begin{array}{l}\text { Al-Shawaf } \\
\text { et al. [35] }\end{array}$ & Unclear & $\begin{array}{l}\text { Yes (sealed } \\
\text { envelopes) }\end{array}$ & No & Unclear & Yes & Yes & Yes & Moderate \\
\hline $\begin{array}{c}\text { Alvarez et al. } \\
{[36]}\end{array}$ & unclear & Unclear & No & Unclear & Yes & Yes & Yes & Moderate \\
\hline $\begin{array}{c}\text { Alvarez et al. } \\
\text { [37] }\end{array}$ & unclear & Unclear & No & Unclear & Yes & Yes & Yes & Moderate \\
\hline $\begin{array}{c}\text { Barisin et al. } \\
\text { [38] }\end{array}$ & $\begin{array}{l}\text { Yes (computer } \\
\text { generated) }\end{array}$ & Yes & $\begin{array}{c}\text { Yes (patients, } \\
\text { doctors, } \\
\text { adjudicators) }\end{array}$ & Unclear & Yes & Yes & Yes & Low \\
\hline $\begin{array}{c}\text { De Hert et al. } \\
{[39]}\end{array}$ & $\begin{array}{l}\text { Yes (computer } \\
\text { generated) }\end{array}$ & $\begin{array}{l}\text { Yes (sealed } \\
\text { envelopes) }\end{array}$ & Yes (adjudicators) & Unclear & Yes & Yes & Yes & Low \\
\hline $\begin{array}{c}\text { De Hert et al. } \\
{[40]}\end{array}$ & $\begin{array}{l}\text { Yes (computer } \\
\text { generated) }\end{array}$ & $\begin{array}{l}\text { Yes (sealed } \\
\text { envelopes) }\end{array}$ & Yes(adjudicators) & Unclear & Yes & Yes & Yes & Low \\
\hline De Luca et al. & Unclear & Unclear & No & Unclear & Yes & Yes & Yes & Moderate \\
\hline $\begin{array}{c}\text { Eriksson et al. } \\
\text { [42] }\end{array}$ & $\begin{array}{l}\text { Yes (permutated } \\
\text { bocks) }\end{array}$ & Yes & $\begin{array}{l}\text { Yes (patients, } \\
\text { doctors) }\end{array}$ & Unclear & Yes & Yes & Yes & Low \\
\hline $\begin{array}{l}\text { Fuhrmann } \\
\text { et al. [33] }\end{array}$ & $\begin{array}{l}\text { Yes (computer } \\
\text { generated) }\end{array}$ & $\begin{array}{l}\text { Yes } \\
\text { (computer } \\
\text { generated) }\end{array}$ & $\begin{array}{l}\text { Yes (patients } \\
\text { doctors) }\end{array}$ & Unclear & Yes & Yes & Yes & Low \\
\hline $\begin{array}{l}\text { Husedzinovic } \\
\text { et al. }\end{array}$ & Yes (casting lots) & Yes & $\begin{array}{l}\text { Yes (patients, } \\
\text { adjudicators) }\end{array}$ & Unclear & Yes & Yes & Yes & Moderate \\
\hline $\begin{array}{c}\text { Jarvela et al. } \\
\text { [44] }\end{array}$ & $\begin{array}{l}\text { Yes (computer } \\
\text { generated) }\end{array}$ & $\begin{array}{l}\text { Yes (sealed } \\
\text { envelopes) }\end{array}$ & $\begin{array}{c}\text { Yes (patients, } \\
\text { doctors, } \\
\text { adjudicators) }\end{array}$ & Unclear & Yes & Yes & Yes & Low \\
\hline $\begin{array}{c}\text { Levin et al. } \\
{[45]}\end{array}$ & $\begin{array}{l}\text { Yes (computer } \\
\text { generated) }\end{array}$ & Unclear & No & Unclear & Yes & Yes & Yes & Moderate \\
\hline $\begin{array}{l}\text { Lilleberg } \\
\text { et al. [46] }\end{array}$ & Unclear & Unclear & $\begin{array}{c}\text { Yes (patients, } \\
\text { doctors, } \\
\text { adjudicators) }\end{array}$ & Unclear & Yes & Yes & Yes & Moderate \\
\hline $\begin{array}{l}\text { Samimi-Fard } \\
\text { et al. [47] }\end{array}$ & Unclear & Unclear & No & Unclear & Yes & Yes & Yes & Moderate \\
\hline$\underset{[48]}{\text { Sonntag et al. }}$ & Unclear & Yes & $\begin{array}{c}\text { Yes (patients, } \\
\text { doctors, } \\
\text { adjudicators) }\end{array}$ & Unclear & Yes & Yes & Yes & Moderate \\
\hline $\begin{array}{l}\text { Tritapepe } \\
\text { et al. [49] }\end{array}$ & $\begin{array}{l}\text { Yes } \\
\text { (computer } \\
\text { generated) }\end{array}$ & Unclear & $\begin{array}{l}\text { Yes (Patients, } \\
\text { physicians, } \\
\text { adjudicators) }\end{array}$ & Unclear & Yes & Yes & Yes & Low \\
\hline $\begin{array}{l}\text { Tritapepe } \\
\text { et al. [1] }\end{array}$ & $\begin{array}{l}\text { Yes (computer } \\
\text { generate) }\end{array}$ & Unclear & $\begin{array}{l}\text { Yes (patients, } \\
\text { physicians, } \\
\text { adjudicators) }\end{array}$ & Unclear & Yes & Yes & Yes & Low \\
\hline
\end{tabular}

treated group (OR $0.54,95 \%$ CI 0.36 to $0.82, P$ for effect $=0.004, P$ for heterogeneity $0.84, \mathrm{I}^{2}=0 \%$ for 465 patients (Figure 5). There was also a significant difference in the length of intensive care stay in favour of levosimendan compared with control (random effects model, mean difference - 26.18 hours $95 \%$ CI 46.20 to $6.16, P$ for heterogeneity $<0.00001, \mathrm{I}^{2}=95 \%, P$ for overall effect $P=0.01$ ) (Figure 6). The likelihood of small study bias robustness was evaluated by inspection of the funnel plot (Figure 7). Inspection of the funnel plot found no major evidence of such bias and added to the validity and robustness of the study. A sensitivity analysis that only included those studies with a low risk of bias (Table 1) found an OR of 0.25 (95\% CI 0.09 to 0.68 ). A further sensitivity analysis to establish differential effects based on the comparator was performed. The largest effect size was observed in the levosimendan versus phosphodiesterase group (OR 0.23 (95\% CI 0.08 to .65)). The levosimendan versus dobutamine group showed a strong trend in favour of levosimendan but was not statistically significant (OR $0.5495 \%$ CI 0.25 to 1.17 )). The levosimendan versus placebo group suggested a positive effect in favour of levosimendan but did not achieve statistical significance (OR 0.66 (95\% CI 0.11 to 4.08$)$ ) (Table 3). 


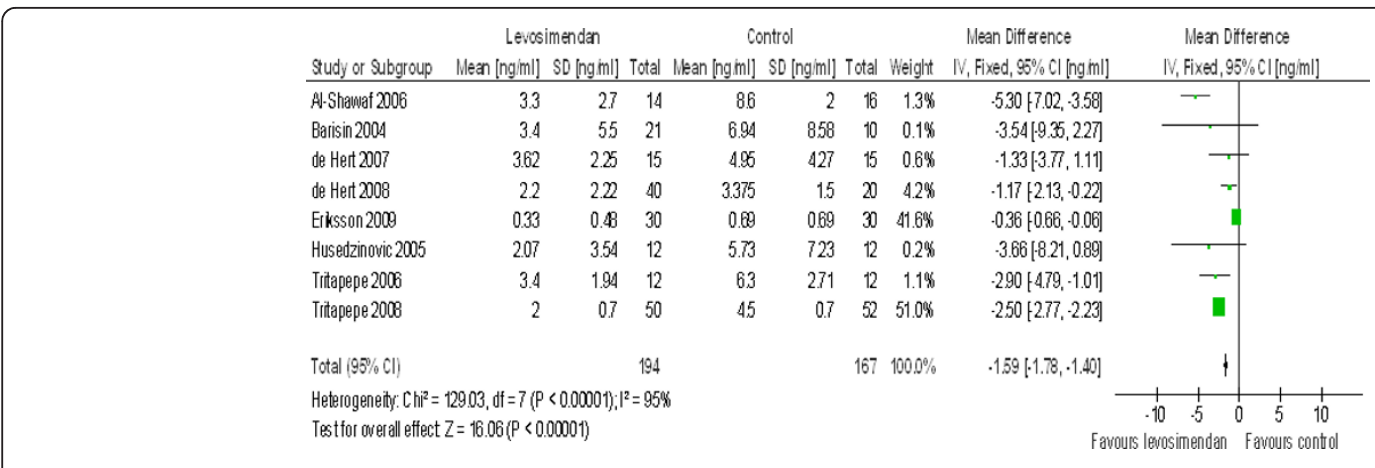

Figure 4 Forest plot of comparison of levosimendan vs control with Troponin I level as the outcome measure outcome.

\section{Discussion}

Cardiogenic shock (CS) is a devastating complication of ST-segment myocardial infarction (STEMI) and occurs in 5 to $8 \%$ of these patients [12]. Thirty-day survival of STEMI patients in cardiogenic shock is between $40 \%$ and $60 \%[12,13]$. Despite favourable trends in the last 30 years, survival to 6 years remains poor and may be as low as 30\% [14-16]. This is comparable to many forms of cancer. Therapeutic options for haemodynamic support after coronary revascularisation are limited to pharmacologic or mechanical interventions. Pharmacologic choices are vasopressors and inotropic drugs. Inotropic agents are essential to address the contractile dysfunction that occurs by providing short-term haemodynamic improvement. However, this happens at a cost of increased oxygen demand, arrythmogenesis and potential myocardial injury at a time when the myocardium is most vulnerable. Data on comparison between inotropes are scant and recent reports have highlighted the challenge in selecting the best pharmacologic option [17-19]. Compared with norepinephrine, the use of dopamine in patients with cardiogenic shock has been associated with an increased rate of death [17].
A recent meta-analysis evaluated the use of levosimendan in a variety of patient populations that included post-cardiac surgery, post-vascular surgery, sepsis, decompensated heart failure and post percutaneous coronary intervention (PCI) patients [20]. The proposed mechanisms of myocardial dysfunction in sepsis, after non-cardiac surgery and in the context of cardiogenic shock, are all quite disparate [21,22]. This implies that vasoactive drugs may perform differently, depending on the prevailing mechanism of shock making the interpretation of a pooled analysis of such a heterogeneous group of patients difficult. For this reason we limited this meta-analysis to patients having coronary revascularisation.

Overall, this study shows a mortality benefit when levosimendan was used in patients having coronary revascularisation. The effect was significant in the elective revascularisation group. The subset of patients undergoing emergency revascularisation was underrepresented and the mortality benefit in this group was not statistically significant. This latter analysis is probably underpowered. Additionally, levosimendan was associated with favourable outcomes in several clinically

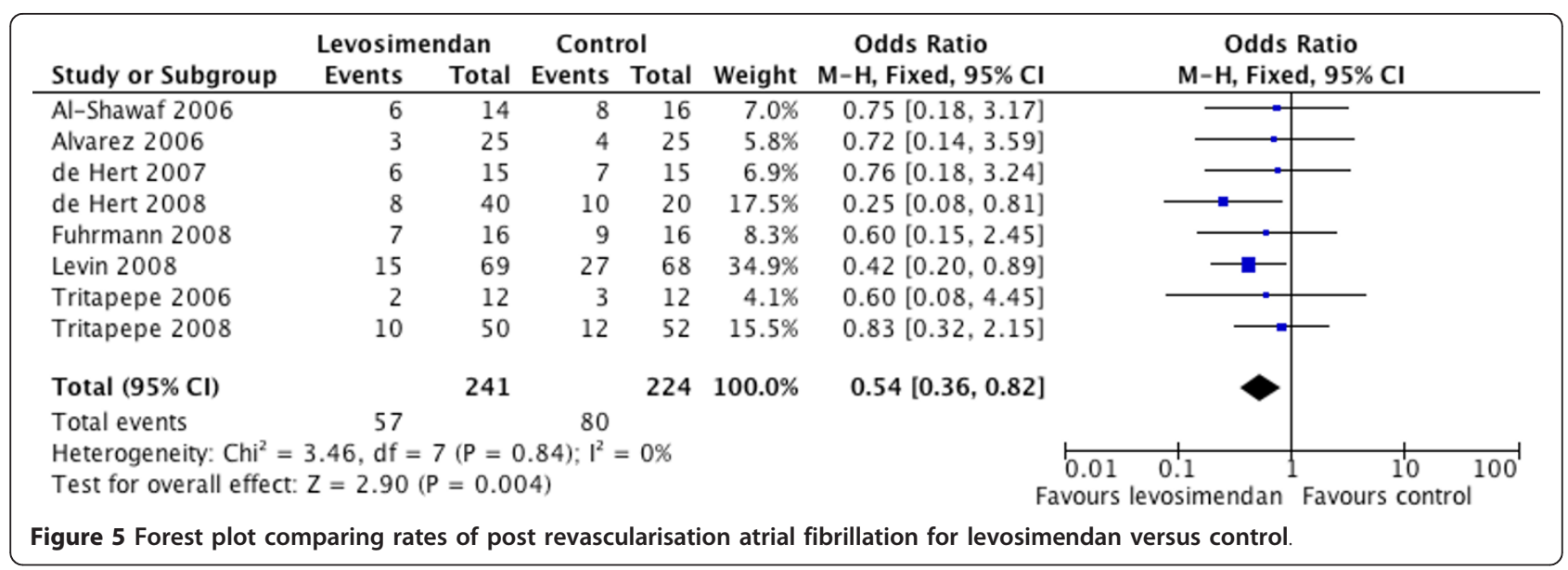




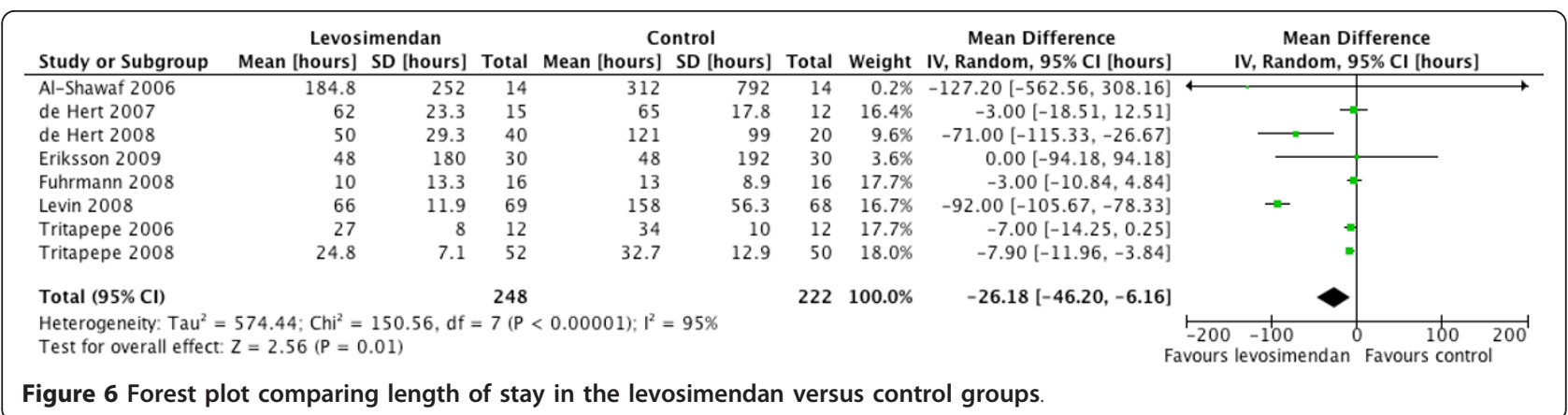

important endpoints. The rate of post-revascularisation atrial fibrillation was reduced. Atrial fibrillation after coronary revascularisation is associated with a prolonged hospital stay, increased morbidity and long-term mortality [23]. The analysis also found levosimendan to be associated with a reduction in peri-procedural cardiac troponin I levels. Elevations in cardiac troponin I levels are a valuable marker of myocardial damage after coronary revascularisation and have been associated with a significantly higher rate of in-hospital and long-term mortality [24-27]. The haemodynamic response to levosimendan was also favourable. It is likely that the improvement of haemodynamic profile observed with levosimendan can be sustained for a longer period of time compared to dobutamine or milrinone [28]. This is because levosimendan has a poorly protein-bound active metabolite and may exert clinical effects for up to a week [29], at a much lower energy expenditure than conventional inotropes.

The sub-group analysis comparing levosimendan to the placebo, dobutamine and phoshodiesterase inhibitors all showed a favourable trend towards levosimendan with only the latter group showing statistical significance. This observation could be interpreted as potential harm from exposure to phosphodiesterase inhibitors.

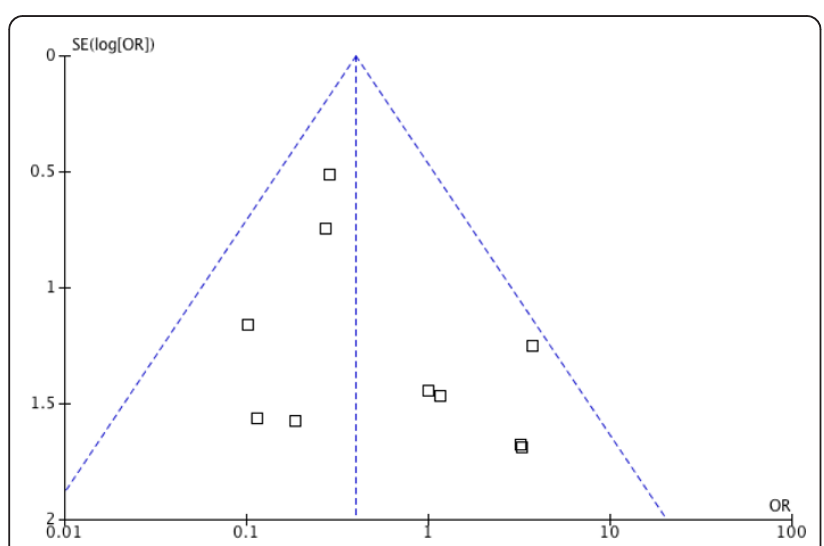

Figure 7 Funnel Plot for risk of mortality including all studies.
Levosimendan reduced the ICU length of stay by a mean of 26.18 hours ( $95 \%$ CI 46.20 to 6.16). The estimated mean cost of critical care is US $\$ 3,518$ /day in the United States and about $£ 1,647 /$ day in the United Kingdom [30,31]. Levosimendan is considerably more expensive than conventional treatment and this probably warrants further pharmaco-economic evaluation.

The findings of this meta-analysis must be viewed in the context of other randomised studies and systematic reviews comparing other vasoactive agents $[17,29,32]$. Thackray et al. systematically reviewed the use of inotropes in cardiac failure [32]. The drugs included were beta agonists, dobutamine, dopexamine and phosphodiesterase inhibitors. Compared with the placebo, these drugs were found to be associated with a non-significant trend for increased rate of death (OR 1.5, 95\% CI 0.51 to 3.92 ).

Our study has several limitations. Several studies were of sub-optimal quality. Eight of the 17 studies included did not have clear allocation concealment. This has the potential to exaggerate treatment effects. Only five studies explicitly stated that the analysis was done by an intention to treat principle. The study by Fuhrmann had a small number of events(i.e. all cause mortality at 30 days) and was stopped early for patient benefit [33]. This study may potentially represent an exaggerated effect size in favour of levosimendan [34]. The sensitivity analysis considering the effect of levosimendan on mortality across comparator drugs showed a more pronounced effect compared with the phosphodiesterase group. Comparing levosimendan to placebo is probably of little value when suitable alternatives exist. These studies recruited low risk patients with a low event rate. Lower event rates require larger sample sizes and it is unsurprising that no statistically significant mortality difference was demonstrated.

Publication bias may account for some of the effects observed. Selective reporting of smaller studies, usually of lower methodological quality will tend to exaggerate treatment effects. The funnel plot was symmetrical, suggesting a low probability of publication bias. Not all 
Table 3 A sensitivity analysis

\begin{tabular}{clllll}
\hline & Number of studies & OR & $\mathbf{9 5 \%} \mathbf{C l}$ & $\boldsymbol{P}$ for overall effect & $\mathbf{I}^{\mathbf{2}} \%$ \\
\hline Studies with low risk of bias & 8 & 0.25 & 0.09 to 0.68 & 0.007 & 0 \\
Levosimendan versus placebo & 9 & 0.66 & 0.11 to 4.08 & 0.65 & 35 \\
Levosimendan versus phosphodiesterase & 4 & 0.23 & 0.08 to 0.65 & 0.003 & 0 \\
Levosimendan versus dobutamine & 4 & 0.54 & 0.25 to 1.17 & 0.12 & 43 \\
\hline
\end{tabular}

A sensitivity analysis including only studies with a low risk of bias, and comparing levosimendan to placebo, phosphodiesterase inhibitors and dobutamine. OR, odds ratio; $\left.\right|^{2}$, heterogeneity

studies reported clinically important outcomes. Only 465 patients were included in the analysis of atrial fibrillation rates and only 470 patients were included in the analysis of length of ICU stay.

\section{Conclusions}

This meta-analysis suggests that the use of levosimendan in patients having coronary revascularisation is associated with a significant reduction in mortality. Additionally, the use of levosimendan is also associated with improvement in haemodynamics and reduction in cardiac biomarkers, length of ICU stay and rate of atrial fibrillation. A suitably powered RCT is required to confirm these findings. Additionally, the exact timing and dosing of levosimendan in patients undergoing coronary revascularisation needs to be specifically addressed.

\section{Key messages}

- Acute cardiovascular dysfunction after coronary revascularisation occurs in about $8 \%$ to $25 \%$ of patients.

- The short-term use of inotropes is crucial to restoring haemodynamics and tissue perfusion though the ideal inotrope in this group of patents is controversial.

- Levosimendan has a potential role in reducing the mortality and morbidity associated with coronary revascularisation.

\section{Additional material}

Additional file 1: Search strategy for PUBMED

Additional file 2: Risk of Bias Table (e Figure 1).

\begin{abstract}
Abbreviations
$\mathrm{Cl}$ : confidence interval; CS: cardiogenic shock; OR: odds ratio; PCl: percutaneous coronary intervention; RR: relative risk; $\mathrm{RCT}$ : randomised controlled trials; STEMI: ST-segment myocardial infarction.
\end{abstract}

\section{Authors' contributions}

All of the authors contributed to the design of the study. RM and VM were responsible for the statistical analysis. RM drafted the manuscript. All of the authors critically revised the manuscript and agreed on the submitted version.

\section{Competing interests}

The authors declare that they have no competing interests.

Received: 10 March 2011 Revised: 29 April 2011 Accepted: 8 June 2011 Published: 8 June 2011

\section{References}

1. Tritapepe L, De Santis V, Vitale D, Guarracino F, Pellegrini F, Pietropaoli P, Singer M: Levosimendan pre-treatment improves outcomes in patients undergoing coronary artery bypass graft surgery. Br J Anaesth 2009, 102:198-204.

2. Lee $\mathrm{CH}$, van Domburg RT, Hoye A, Lemos PA, Tanabe K, Smits PC, van der Giessen WJ, de Feyter P, Serruys PW: Predictors of survival after contemporary percutaneous coronary revascularization for acute myocardial infarction in the real world. J Invasive Cardiol 2004, 16:627-631.

3. Holmes DR Jr, Califf RM, Van de Werf F, Berger PB, Bates ER, Simoons ML, White HD, Thompson TD, Topol EJ: Difference in countries' use of resources and clinical outcome for patients with cardiogenic shock after myocardial infarction: results from the GUSTO trial. Lancet 1997, 349:75-78.

4. Pae WE Jr, Miller CA, Matthews Y, Pierce WS: Ventricular assist devices for postcardiotomy cardiogenic shock. A combined registry experience. J Thorac Cardiovasc Surg 1992, 104:541-552, discussion 552-543.

5. Mebazaa A, Pitsis AA, Rudiger A, Toller W, Longrois D, Ricksten SE, Bobek I, De Hert S, Wieselthaler G, Schirmer U, von Segesser LK, Sander M, Poldermans D, Ranucci M, Karpati PC, Wouters P, Seeberger M, Schmid ER, Weder W, Follath F: Clinical review: practical recommendations on the management of perioperative heart failure in cardiac surgery. Crit Care $14: 201$.

6. Feneck RO, Sherry KM, Withington PS, Oduro-Dominah A: Comparison of the hemodynamic effects of milrinone with dobutamine in patients after cardiac surgery. J Cardiothorac Vasc Anesth 2001, 15:306-315.

7. Fowler MB, Alderman EL, Oesterle SN, Derby G, Daughters GT, Stinson EB, Ingels NB, Mitchell RS, Miller DC: Dobutamine and dopamine after cardiac surgery: greater augmentation of myocardial blood flow with dobutamine. Circulation 1984, 70:1103-111.

8. Pagel PS: Levosimendan in cardiac surgery: a unique drug for the treatment of perioperative left ventricular dysfunction or just another inodilator searching for a clinical application? Anesth Analg 2007, 104:759-761.

9. MetaRegister of Controlled Clinical Trials. [http://www.controlled-trials. $\mathrm{com} / \mathrm{mrct}]$.

10. Moher D, Liberati A, Tetzlaff J, Altman DG, PRISMA Group: Preferred reporting items for systematic reviews and meta-analyses: the PRISMA statement. BMJ 2009, 339:b2535.

11. Liberati A, Altman DG, Tetzlaff J, Mulrow C, Gotzsche PC, loannidis JP, Clarke M, Devereaux PJ, Kleijnen J, Moher D: The PRISMA statement for reporting systematic reviews and meta-analyses of studies that evaluate healthcare interventions: explanation and elaboration. BMJ (Clin Res Educ) 2009, 339:b2700.

12. Reynolds HR, Hochman JS: Cardiogenic shock: current concepts and improving outcomes. Circulation 2008, 117:686-697.

13. Dauerman HL, Goldberg RJ, White K, Gore JM, Sadiq I, Gurfinkel E, Budaj A Lopez de Sa E, Lopez-Sendon J, Global Registry of Acute Coronary Events. GRACE Investigators: Revascularization, stenting, and outcomes of patients with acute myocardial infarction complicated by cardiogenic shock. Am J Cardiol 2002, 90:838-842.

14. Hochman JS, Sleeper LA, Webb JG, Dzavik V, Buller CE, Aylward P, Col J, White HD: Early revascularization and long-term survival in cardiogenic 
shock complicating acute myocardial infarction. JAMA 2006, 295:2511-2515.

15. Singh M, White J, Hasdai D, Hodgson PK, Berger PB, Topol EJ, Califf RM, Holmes DR Jr: Long-term outcome and its predictors among patients with ST-segment elevation myocardial infarction complicated by shock: insights from the GUSTO-I trial. J Am Coll Cardiol 2007, 50:1752-1758.

16. Goldberg RJ, Spencer FA, Gore JM, Lessard D, Yarzebski J: Thirty-year trends (1975 to 2005) in the magnitude of, management of, and hospital death rates associated with cardiogenic shock in patients with acute myocardial infarction: a population-based perspective. Circulation 2009, 119:1211-1219.

17. De Backer D, Biston P, Devriendt J, Madl C, Chochrad D, Aldecoa C, Brasseur A, Defrance $P$, Gottignies $P$, Vincent $J$ : Comparison of dopamine and norepinephrine in the treatment of shock. N Engl J Med 2010, 362:779-789.

18. Parissis JT, Rafouli-Stergiou P, Stasinos V, Psarogiannakopoulos P, Mebazaa A: Inotropes in cardiac patients: update 2011. Curr Opin Crit Care 2010, 16:432-441.

19. Mebazaa A, Pitsis AA, Rudiger A, Toller W, Longrois D, Ricksten SE, Bobek I, De Hert S, Wieselthaler G, Schirmer U, von Segesser LK, Sander M, Poldermans D, Ranucci M, Karpati PC, Wouters P, Seeberger M, Schmid ER, Weder W, Follath F: Clinical review: practical recommendations on the management of perioperative heart failure in cardiac surgery. Crit Care 2010, 14:201.

20. Guarracino F, Landoni G, Baldassarri R, Nobile L, Stefani M: Concomitant levosimendan and esmolol infusion in ischaemic cardiogenic shock. $\mathrm{Br} J$ Anaesth 2010, 104:388-389.

21. Poli-de-Figueiredo LF, Garrido AG, Nakagawa N, Sannomiya P: Experimental models of sepsis and their clinical relevance. Shock 2008, 30(Suppl 1):53-59.

22. Hunter JD, Doddi M: Sepsis and the heart. Br J Anaesth 2010, 104:3-11.

23. Mariscalco G, Klersy C, Zanobini M, Banach M, Ferrarese S, Borsani P, Cantore C, Biglioli P, Sala A: Atrial fibrillation after isolated coronary surgery affects late survival. Circulation 2008, 118:1612-1618.

24. Alcock RF, Roy P, Adorini K, Lau GT, Kritharides L, Lowe HC, Brieger DB, Freedman SB: Incidence and determinants of myocardial infarction following percutaneous coronary interventions according to the revised Joint Task Force definition of troponin T elevation. Int J Cardiol 2010, 140:66-72.

25. Lurati Buse GA, Koller MT, Grapow M, Bolliger D, Seeberger M, Filipovic M: The prognostic value of troponin release after adult cardiac surgery - a meta-analysis. Eur J Cardiothorac Surg 2010, 37:399-406.

26. van Geene Y, van Swieten HA, Noyez L: Cardiac troponin I levels after cardiac surgery as predictor for in-hospital mortality. Interact Cardiovasc Thorac Surg 2010, 10:413-416.

27. Paparella D, Scrascia G, Paramythiotis A, Guida P, Magari V, Malvindi PG, Favale S, de Luca Tupputi Schinosa L: Preoperative cardiac troponin I to assess midterm risks of coronary bypass grafting operations in patients with recent myocardial infarction. Ann Thorac Surg 2010, 89:696-702.

28. Szilagyi S, Pollesello P, Levijoki J, Kaheinen P, Haikala H, Edes I, Papp Z: The effects of levosimendan and OR-1896 on isolated hearts, myocyte-sized preparations and phosphodiesterase enzymes of the guinea pig. Eur $J$ Pharmacol 2004, 486:67-74.

29. Toller WG, Stranz C: Levosimendan, a new inotropic and vasodilator agent. Anesthesiology 2006, 104:556-569.

30. Halpern NA, Pastores SM: Critical care medicine in the United States 2000-2005: an analysis of bed numbers, occupancy rates, payer mix, and costs. Crit Care Med 2010, 38:65-71.

31. Hutchings A, Durand MA, Grieve R, Harrison D, Rowan K, Green J, Cairns J, Black N: Evaluation of modernisation of adult critical care services in England: time series and cost effectiveness analysis. BMJ 2009, 339:b4353.

32. Thackray S, Easthaugh J, Freemantle N, Cleland JG: The effectiveness and relative effectiveness of intravenous inotropic drugs acting through the adrenergic pathway in patients with heart failure-a meta-regression analysis. Eur J Heart Fail 2002, 4:515-529.

33. Fuhrmann JT, Schmeisser A, Schulze MR, Wunderlich C, Schoen SP, Rauwolf T, Weinbrenner C, Strasser RH: Levosimendan is superior to enoximone in refractory cardiogenic shock complicating acute myocardial infarction. Crit Care Med 2008, 36:2257-2266.

34. Briel M, Montori VM, Lane M, Glasziou P, Zhou Q, Heels-Ansdell D, Walter SD, Guyatt GH, Flynn DN, Elamin MB, Murad MH, Abu Elnour NO,
Lampropulos JF, Sood A, Mullan RJ, Erwin PJ, Bankhead CR, Perera R, Ruiz Culebro C, You JJ, Mulla SM, Kaur J, Nerenberg KA, Schünemann H, Cook DJ, Lutz K, Ribic CM, Vale N, Malaga G, et al: Stopping randomized trials early for benefit and estimation of treatment effects: systematic review and meta-regression analysis. JAMA 303:1180-1187.

35. Al-Shawaf E, Ayed A, Vislocky I, Radomir B, Dehrab N, Tarazi R: Levosimendan or milrinone in the type 2 diabetic patient with low ejection fraction undergoing elective coronary artery surgery. $J$ Cardiothorac Vasc Anesth 2006, 20:353-357.

36. Alvarez J, Taboada M, Rodriguez J, Caruezo V, Bouzada M, Campana O, Bascuas B, Perez-Paz J, Ginesta V: [Hemodynamic effects of levosimendan following cardiac surgery]. Rev Esp Anestesiol Reanim 2005, 52:389-394.

37. Alvarez J, Bouzada M, Fernandez AL, Caruezo V, Taboada M, Rodriguez J, Ginesta V, Rubio J, Garcia-Bengoechea JB, Gonzalez-Juanatey JR: [Hemodynamic effects of levosimendan compared with dobutamine in patients with low cardiac output after cardiac surgery]. Rev Esp Cardiol 2006, 59:338-345.

38. Barisin S, Husedzinovic I, Sonicki Z, Bradic N, Barisin A, Tonkovic D: Levosimendan in off-pump coronary artery bypass: a four-times masked controlled study. J Cardiovasc Pharmacol 2004, 44:703-708.

39. De Hert SG, Lorsomradee S, Cromheecke S, Van der Linden PJ: The effects of levosimendan in cardiac surgery patients with poor left ventricular function. Anesth Analg 2007, 104:766-773.

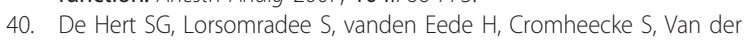
Linden PJ: A randomized trial evaluating different modalities of levosimendan administration in cardiac surgery patients with myocardial dysfunction. J Cardiothorac Vasc Anesth 2008, 22:699-705.

41. De Luca L, Proietti P, Celotto A, Bucciarelli-Ducci C, Benedetti G, Di Roma A, Sardella G, Genuini I, Fedele F: Levosimendan improves hemodynamics and coronary flow reserve after percutaneous coronary intervention in patients with acute myocardial infarction and left ventricular dysfunction. Am Heart J 2005, 150:563-568.

42. Eriksson HI, Jalonen JR, Heikkinen LO, Kivikko M, Laine M, Leino KA, Kuitunen AH, Kuttila KT, Peräkylä TK, Sarapohja T, Suojaranta-Ylinen RT, Valtonen M, Salmenperä MT: Levosimendan facilitates weaning from cardiopulmonary bypass in patients undergoing coronary artery bypass grafting with impaired left ventricular function. Ann Thorac Surg 2009, 87:448-454.

43. Husedzinovic I, Barisin S, Bradic N, Barisin A, Sonicki Z, Milanovic R: Levosimendan as a new strategy during off-pump coronary artery bypass grafting: double-blind randomized placebo-controlled trial. Croat Med J 2005, 46:950-956.

44. Jarvela K, Maaranen P, Sisto T, Ruokonen E: Levosimendan in aortic valve surgery: cardiac performance and recovery. J Cardiothorac Vasc Anesth 2008, 22:693-698.

45. Levin RL, Degrange MA, Porcile R, Salvagio F, Blanco N, Botbol AL, Tanus E, del Mazo CD: [The calcium sensitizer levosimendan gives superior results to dobutamine in postoperative low cardiac output syndrome]. Rev Esp Cardiol 2008, 61:471-479.

46. Lilleberg J, Nieminen MS, Akkila J, Heikkila L, Kuitunen A, Lehtonen L, Verkkala K, Mattila S, Salmenpera M: Effects of a new calcium sensitizer, levosimendan, on haemodynamics, coronary blood flow and myocardial substrate utilization early after coronary artery bypass grafting. Eur Heart J 1998, 19:660-668.

47. Samimi-Fard S, Garcia-Gonzalez MJ, Dominguez-Rodriguez A, AbreuGonzalez P: Effects of levosimendan versus dobutamine on long-term survival of patients with cardiogenic shock after primary coronary angioplasty. Int I Cardiol 2008, 127:284-287.

48. Sonntag S, Sundberg S, Lehtonen LA, Kleber FX: The calcium sensitizer levosimendan improves the function of stunned myocardium after percutaneous transluminal coronary angioplasty in acute myocardial ischemia. J Am Coll Cardiol 2004, 43:2177-2182.

49. Tritapepe L, De Santis V, Vitale D, Santulli M, Morelli A, Nofroni I, Puddu PE, Singer M, Pietropaoli P: Preconditioning effects of levosimendan in coronary artery bypass grafting-a pilot study. Br J Anaesth 2006, 96:694-700.

doi:10.1186/cc10263

Cite this article as: Maharaj and Metaxa: Levosimendan and mortality after coronary revascularisation: a meta-analysis of randomised controlled trials. Critical Care 2011 15:R140. 